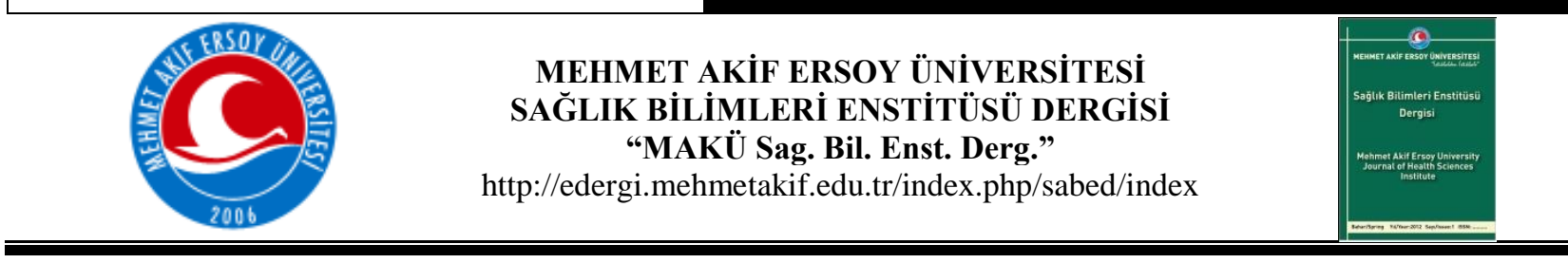

\title{
BVD ve BHV-1 ile Tek ve Çift İnfeksiyonlarda Bazı Akut Faz Proteinleri ve Hepcidin Düzeyleri
}

\author{
Some Acute Phase Proteins and Hepcidin Levels in Single and Dual Infection \\ with BVD and BHV-1
}

\author{
Sima Sahinduran ${ }^{1 *}$, Mehmet Kale ${ }^{2}$, Reyda Kıyıc ${ }^{1}$, Necmettin Sarp Sevgisunar ${ }^{1}$ \\ ${ }^{1}$ Department of Internal Medicine, Faculty of Veterinary Medicine, University of Mehmet Akif Ersoy, Burdur, \\ Turkey \\ ${ }^{2}$ Department of Virology, Faculty of Veterinary Medicine, University of Mehmet Akif Ersoy, Burdur, Turkey.
}

\begin{abstract}
In this study it was aimed to determine serum amyloid A, haptoglobin and especially hepcidin concentrations in animals with dual (Bovine viral diarrhea virus / Bovine herpesvirus -1) and single infections (Bovine viral diarrhea virus or Bovine herpesvirus -1) and reference ranges of hepcidin in healthy clinicaly cattle. Previously, studies have been conducted on only hepcidin gene but hepcidin values has not been studied in cattle diseases.

In this study totaly 56 cattle were used. In 17 of them Bovine herpesvirus-1, 13 of them Bovine viral diarrhea virus, 4 of them both Bovine herpesvirus-1 and Bovine viral diarrhea virus were diagnosed. The control group was composed of 22 clinicaly healthy animals. According to the results animals naturally infected with dual infection did not show more significant differences level of acute phase proteins compared to animals with single infection. Serum hepcidin values were not differ between the 3 trial groups. But there were significant differences in three trial groups results when compared with control group $(\mathrm{P}<0.001)$. Results of haptoglobin analysis were similar to the results of hepcidin analysis.

We demonstrated the normal ranges of hepcidin in 22 clinically healthy cows. According to these results, we can suggest that the hepcidin can be used as a marker for the diagnosis of the diseases as an acute phase protein.
\end{abstract}

Key words: Bovine viral diarrhea, Bovine herpesvirus, acute phase proteins, hepcidin.

Yazışma Adresi Prof. Dr. Sima Sahinduran Department of Internal Medicine,

Faculty of Veterinary Medicine, University of Mehmet Akif Ersoy, Burdur,

Turkey.

E-posta: sahinduran@mehmetakif.edu.tr

Fax: +902482132001
Öz: $\mathrm{Bu}$ çalışmanın amacı, ikili (Bovine viral diarrhea virus / Bovine herpesvirus -1) ve tek enfeksiyonlu (Bovine viral diarrhea virus veya Bovine herpesvirus -1) hayvanlarda ve ayrıca sağlıklı sığırlarda serum amiloid A, haptoglobin ve özellikle hepcidin konsantrasyonlarını belirlemekti. Daha önce sadece hepcidin geni üzerinde çalışmalar yapılmış olup ancak sığır hastalıklarında hepcidin değerleri araştırılmamıştır.

Bu çalışmada toplam 56 sığır kullanılmıştır. Onlardan 17'inde Bovine herpesvirus-1, 13 tanesinde Bovine viral diarrhea virüsü, bunların 4'ünde ise hem Bovine herpesvirus-1 hem Bovine viral diarrhea virüsü tespit edildi. Kontrol grubu ise 22 sağlıklı sığırdan oluşturuldu. Bulgulara göre, çift infeksiyonlu hayvanlar ile tek enfeksiyonlu hayvanlar arasinda akut faz proteinlerinin seviyelerinde belirgin farklılık saptanmamıştır. Serum hepcidin değerleri, 3 çalışma grubu arasında farklılık göstermedi. Fakat üç deneme grubunda kontrol grubuna göre anlamlı farklılıklar vardı $(\mathrm{P}<0.001)$. Haptoglobin değerleri hepcidin değerlerine yakın bulundu.

$\mathrm{Bu}$ çalışma ile ilk defa sağlıklı sığırlarda hepcidin'in normal değerleri saptanmaya çalışıldı. Bu sonuçlara göre, hepcidin, bir akut faz proteini olarak hastalıkların teşhisi için bir marker olarak kullanılabileceği önerilebilir.

Anahtar sözcükler: Bovine viral diarrhea, Bovine herpesvirus, akut faz proteinleri, hepcidin.

Geliş Tarihi: 20.07.2017 Kabul Tarihi: 21.11.2017

Kaynak göstermek için: Sahinduran S, Kale M, Kıyıcı R, Sevgisunar N.S. 2017 BVD ve BHV-1 ile tek ve çift infeksiyonlarda bazı akut faz proteinleri ve hepcidin düzeyleri. MAKÜ Sag. Bil. Enst. Derg. 5(2): 115-123. 


\section{Introduction}

Bovine viral diarrhea virus (BVDV) is an enveloped RNA virus of the genus Pestivirus in family Flaviviridae (Smith, 2009). Pestiviruses are known for their ability to aggravate transplacental infection and depending on the stage of gestation at which the infection takes place it may result in fetal death, malformation, anomalies in neonate, or immune tolerance and lifelong viral persistence. In immune competent animals, depending on the virulence of the virus strain involved, the clinical outcome ranges from subclinical or very mild and in the majority of cases to acute fatal disease (Hamers et al. 2001). In ruminant pestiviruses, particularly BVDV, there are two biotypes designated as non-cytopathic (nCP) and cytopathic $(\mathrm{CP})$ depending on their effect on tissue culture cells. The nCP type is the most important biotype (Radostits et al. 2008) and in the immunologically immature fetus leads to lifelong virus persistence (Swasdipan et al. 2002).

Infectious Bovine Rhinotracheitis (IBR) is a herpesvirus (BHV-1) that involve the respiratory or reproductive tracts, nervous system, conjunctiva. It also may cause widespread systemic disease (Smith, 2009), and is involved in the Bovine Respiratory Disease Complex with other bacterial and viral pathogens such as BVDV (Srikumaran et al. 2008).

The acute phase proteins (APP) are blood proteins and their concentration changes in animals exposed to external or internal pathological events such as inflammation, infection, surgical trauma or stress (Eckersall, 2000; Eckersall and Bell, 2010). In bovine, as markers of inflammation, APPs levels usually increase significantly during the course of acute and chronic infections. APPs have been widely used in veterinary medicine as a marker of animal health and as an indicator of disease severity and prognosis (Eckersall, 2000). Haptoglobin (Hp) and serum amyloid A (SAA) are the most important APPs in cattle in the disease processes especially in viral infections (Genheim et al. 2003).

Hepcidin is a conserved 25- amino acid peptide and primarily produced in liver and can be detected in blood and urine (Park et al. 2001). It has been firstly identified as an antimicrobial peptide in human blood and urine (Krause et al.2000; Park et al. 2001), but consequent researches have revealed that it is a type II acute phase reactant (Nemeth et al. 2003), and also a mediator for anemia of inflammation (Weinstein et al. 2002). 
The purpose of this study was to demonstrate the values of some imflammatory mediators and especially hepcidin in healthy cattle and in those with IBR, BVDV and also in cattle with both BVDV and IBR that never been studied before, according to our literature researches.

\section{Material and Methods}

\section{Location of study}

This study was performed in Burdur province which is located in Akdeniz region at south-west of Turkey. Burdur province has one of the highest populations of cattle in Turkey. Burdur has a continental Mediterranean climate with cold, snowy winters and hot, long and dry summers.

\section{Animal material and anamnesis}

In September 2012, an owner of a cattle farm from the province of Burdur situated in the Southern West part of Turkey, was admitted to the faculty of veterinary clinics with complaint of decrease in milk and fertility yield in farm animals. According to the history taken from the owner, the animals were from 9 months to 7 years old. Some of the young cattle suffered from diarrhea (In some of them with bloody diarrhea), and in the some of the old, fertility declined and decreased milk yield were observed. These symptoms had been observed for last 5-6 months.

\section{Clinical examinations}

The farm was visited by the veterinarian of the Veterinary Teaching Hospital of the Faculty of Veterinary Medicine, University of Mehmet Akif Ersoy. Total number of 56 animals were kept in the farm. Forty of them were over one-year-old and 16 of them were under one-year-old. All the cattle were Holstein and the herd had a history of 5-6 months of disease. The weakness and mild respiratory distress was seen in some of the animals. Fever was measured randomly in 10 animals and high fever was detected in 2 of them.

All of animals were free of tuberculosis, brucellosis, pasteurellosis and bovine leucosis. No animals (adults and young) were vaccinated against BVDV and BHV-1. Diarrhea (sometimes bloody diarrhea) in young animals and fertility disorders in adult animals aroused suspicion of BVDV or IBR in these animals. 


\section{Serological Examinations}

All of animals were tested for BVDV and BHV-1 viruses. Thus blood samples were collected from all of the animals and then blood serum samples were tested for antibodies to BVDV and BHV-1 and leukocyte samples were screened for BVDV antigens using ELISA methods. Commercial ELISA kits ${ }^{1,2}$ were used for detection BVDV antigens and antibodies against BVDV. Then all serum samples were tested for BHV-1 antibodies using a commercial BHV-1 ELISA test $\mathrm{kit}^{3}$. All blood samples were recollected from animals after 21 days for recontrol of the BHV-1 antibodies and after 45 days for recontrol of the BVDV antibodies and antigens.

After applying the tests, some animals showed dual and some showed single infection. On the other hand there were animals without any infection.

\section{Haematological analysis and Measurement of Acute Phase Proteins}

After the diagnosis, blood samples were collected from all animals. MS9 blood counting equipment was used for haematological analysis of the blood drawn in EDTA tubes. The levels of haptoglobin, serum amiloid $\mathrm{A}$ and hepcidin were determinated by use of the commertial kits. Haptoglobin level in serum was determined by the haemoglobin binding method using micro-titre plates and SAA and hepcidin were measured by sandwich ELISA using SAA kits in ELISA reader according to the manufacturer's instructions.

\section{Statistical Analyses}

One-way analysis of variance test was used to detect any differences between infected and control groups for haematological and acute phase proteins. In the determination of differences, Student'st-test was used. Calculations were performed by using the SPSS 10.0 program pack (SPSS, Chicago, IL). A $\mathrm{P}<0.05$ value was accepted as statistically significant.

\section{Results}

The age of the infected animals ranged from 9 months to 7 years, and all had a history of 5-6 months of disease. The weakness and mild respiratory distress was seen in most of the animals. No animals (adults and young) were vaccinated against BVDV and BHV-1. For this reason all of animals were tested for BVDV and BHV-1 viruses. The same results were obtained in the second samples of the blood serum and leucocytes. After the assay in 17 of 
them BHV-1 (antibody positive), 13 of them BVDV (antigen positive/antibody negative and antigen positive/antibody positive), 4 of them both BHV-1 (antibody positive) and BVDV (antigen positive/antibody negative and antigen positive/antibody positive) were diagnosed. In the remaining 22 animals, there was no any infection. Relationship between animals ages and their infections is shown in Table 1.

Table1: Relationship between animals ages and their infections.

\begin{tabular}{lcccc}
\hline Age of animals & $\begin{array}{c}\text { Animals with } \\
\text { BHV-1 infection }\end{array}$ & $\begin{array}{c}\text { Animals with } \\
\text { BVDV infection }\end{array}$ & $\begin{array}{c}\text { Animals with } \\
\text { both BHV-1 and } \\
\text { BVDV infection }\end{array}$ & $\begin{array}{c}\text { Animals with not } \\
\text { any infection }\end{array}$ \\
\hline Over one year of age & 13 & 3 & 4 & 12 \\
$\begin{array}{l}\text { Under one year of age } \\
\text { Totally of animals }\end{array}$ & 4 & 10 & 0 & 10 \\
\hline
\end{tabular}

The mean values of haematological parameters in four groups are shown in Table 2. In this table only parameters by significant differences are shown and there were no significant changes in other parameters.

Table 2: Mean haematological values in 3 infected groups and healthy group.

\begin{tabular}{|c|c|c|c|c|c|}
\hline Parameters & $\begin{array}{c}\text { Animals with } \\
\text { BHV-1 } \\
\text { infection }\end{array}$ & $\begin{array}{c}\text { Animals with } \\
\text { BVDV } \\
\text { infection }\end{array}$ & $\begin{array}{c}\text { Animals with } \\
\text { both BHV-1 } \\
\text { and BVDV } \\
\text { infection }\end{array}$ & $\begin{array}{l}\text { Animals } \\
\text { without } \\
\text { infection }\end{array}$ & $\mathbf{p}$ \\
\hline $\begin{array}{l}\text { Total leukocyte } \\
\left(\times 10^{9} / \mathrm{L}\right)\end{array}$ & $3.92 \pm 0.74^{\mathrm{a}}$ & $4.02 \pm 0.63^{\mathrm{a}}$ & $3.69 \pm 0.58^{\mathrm{a}}$ & $9.44 \pm 1.99^{\mathrm{b}}$ & $<0.001^{* * *}$ \\
\hline Erythrocyte (x10 $12 / 1)$ & $8.88 \pm 1.00^{\mathrm{a}}$ & $8.54 \pm 0.98^{\mathrm{a}}$ & $4.15 \pm 0.46^{\mathrm{b}}$ & $9.20 \pm 0.90^{\mathrm{a}}$ & $<0.001^{m-m}$ \\
\hline Haemoglobin(g/dl) & $9.43 \pm 1.38^{\mathrm{a}}$ & $9.11 \pm 0.59^{\mathrm{a}}$ & $5.38 \pm 0.10^{\mathrm{b}}$ & $11.22 \pm 1.53^{\mathrm{c}}$ & $<0.001^{\mathrm{mm}}$ \\
\hline Haematocrit $(\%)$ & $30.19 \pm 4.91^{\mathrm{a}}$ & $31.02 \pm 6.12^{\mathrm{a}}$ & $22.17 \pm 2.31^{\mathrm{b}}$ & $32.14 \pm 4.83^{\mathrm{a}}$ & $<0.01^{m}$ \\
\hline Thrombocyte $\left(\times 10^{9} / \mu \mathrm{l}\right)$ & $349.29 \pm 58.27^{\mathrm{a}}$ & $85.92 \pm 12.77^{\mathrm{b}}$ & $57.25 \pm 1.50^{\mathrm{b}}$ & $356.31 \pm 60.77^{\mathrm{a}}$ & $<0.001^{m-m}$ \\
\hline
\end{tabular}

The mean values of serum amyloid A, haptoglobin and hepcidin in four groups are shown in Table 3. There were significant differences in SAA, Hp and hepcidin concentrations between three infected groups compared to control group $(\mathrm{P}<0.001)$. 
BVD ve BHV-1 ile tek ve çift infeksiyonlarda bazı akut faz proteinleri ve hepcidin düzeyleri Some acute phase proteins and hepcidin levels in single and dual infection with BVD and BHV-1

Table 3: Mean values of serum SAA, Hp and Hepcidin in 3 infected groups and healthy group.

\begin{tabular}{cccccc}
\hline Parameters & $\begin{array}{c}\text { Animals with } \\
\text { BHV-1 } \\
\text { infection }\end{array}$ & $\begin{array}{c}\text { Animals with } \\
\text { BVDV } \\
\text { infection }\end{array}$ & $\begin{array}{c}\text { Animals with } \\
\text { both BHV-1 } \\
\text { and BVDV } \\
\text { infection }\end{array}$ & $\begin{array}{c}\text { Animals } \\
\text { without } \\
\text { infection }\end{array}$ & p \\
\hline SAA $(\boldsymbol{\mu g} / \mathbf{m l})$ & $105.72 \pm 20.96^{\mathrm{a}}$ & $90.63 \pm 12.94^{\mathrm{b}}$ & $98.25 \pm 9.33^{\mathrm{ab}}$ & $32.86 \pm 6.44^{\mathrm{c}}$ & $0.001^{* * *}$ \\
$\begin{array}{c}\text { Haptoglobin } \\
\mathbf{( m g / m l )}\end{array}$ & $1.49 \pm 0.55^{\mathrm{a}}$ & $1.76 \pm 0.42^{\mathrm{a}}$ & $1.45 \pm 0.42^{\mathrm{a}}$ & $0.23 \pm 0.04^{\mathrm{b}}$ & $0.001^{* * *}$ \\
\begin{tabular}{c} 
Hepcidin $(\mathbf{n g} / \mathbf{m l})$ \\
\hline
\end{tabular} & $85.91 \pm 15.50^{\mathrm{a}}$ & $80.73 \pm 7.30^{\mathrm{a}}$ & $83.55 \pm 7.08^{\mathrm{a}}$ & $15.93 \pm 0.84^{\mathrm{b}}$ & $0.001^{* * * *}$ \\
\hline
\end{tabular}

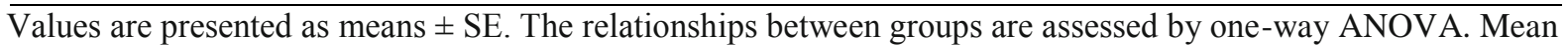
values are significantlydifferent from each other $(\mathrm{p}<0.01$ and $\mathrm{p}<0.001)$

** Moderately significant; ***highly significant

\section{Discussion and Conclusion}

The material of this study consists of four groups of animals. BHV-1 was detected in animals in the first group $(n=17)$. BVDV has been detected in the second group $(n=13)$. In the third group 4 animals were detected with dual infections of BHV-1 and BVDV. Finally control group consisted of 22 animals without showing any clinical symptoms. Most of the animals in BHV-1 infection group were over one year of age $(n=13)$ whereas, the most of animals in BVDV infection group were under one year of age $(n=10)$. All animals showing dual infection, were over one year of age $(n=4)$.

The most frequent form of BVDV infection in cattle is non-clinical or a mild diseases of high morbidity and low case fatality characterized by a mild fever, leukopenia, inappetence and mild diarrhea (Radostits et al. 2008).

In this study, the number of total leukocyte decreased in animals with single and dual infection and leukopenia was dominant in these animals. But they showed significant differences compared to control group.

There was no significant difference between BHV-1 and BVDV groups, in therm of the count of erythrocyte and haematocrit level. The number of erythrocyte and haematocrit level were in normal ranges in two groups. On the other hand the number of erythrocyte and haematocrit level in animals with dual infections (BHV-1/BVDV group) was significantly lower in comparison with control and other groups $(\mathrm{P}<0.001)$. Despite diarrhea, decline of haematocrit values in animals with dual infections (BHV-1/BVDV group), could be due to the severe haemorrhagic diarrhea in these animals. 
Haemoglobin level did not differ between the two groups (BHV-1 and BVDV), but the level of haemoglobin appeared much lower in the dual infection group compared with the control group $(\mathrm{P}<0.001)$. According to these results, severe anemia was detected in the dual infection group (BHV-1/BVDV group).. In this study more significant differences were seen in the hematological values of animals with the dual infection (BHV-1/BVDV).

Bovine viral diarrhea virus causes thrombocytopenia and the decrease of this parameter is due to the severe of the infection (Lindberg, 2003). Thrombocytopenia and the hemorrhagic syndrome can be occurs in adult cattle and calves affected with the peracute form of BVDV infection. Thrombocyte counts are reduced and clinically are bloody diarrhea, ets. Anemia and bone marrow necrosis can ocur in beef calves naturally infected with type 2 strains of the virus (Radostits et al. 2008). In our study thrombocyte count of the BVDV infected and dual infected groups showed a significant decrease compared to the BHV-1 and control groups $(\mathrm{P}<0.001)$.

One of the main aims of milk producers is to keep a healthy flock for a long-term high milk production. Keeping a healthy herd means ensures an optimal reproduction level and milk production. Early detection of the risk for a disease should protect the majority of animals within a herd (Jawor and Stefaniak, 2011).

Acute phase protein measurements may be used to monitor the health and welfare of animals on farms (Eckersall, 2000). In ruminants, haptoglobin is a major APP (Eckersall and Bell, 2010). Risalde et al., (2011) reported that serum levels of Hp did not change in animals infected with single agent and animals infected with dual infection. In our study, serum levels of haptoglobin showed no significant change in all three groups (single and dual infections) but significant differences detected when compared with control group $(\mathrm{P}<0.001)$. According to our results, Hp levels may not change in animals infected with BVDV, BHV-1 and BVDV/BHV-1. This finding is in agreement with the previous study. In the same investigation, researchers reported that SAA levels showed a significant increase in animals of the BVDV/BHV-1 group, whereas the animals of the BHV-1 group did not present any changes. In this study, the serum amyloid A presented difference in magnitude between single (BVDV and BHV-1) and dual (BVDV/BHV-1) infections compared to control group $(\mathrm{P}<0.001)$. However, it showed no significant difference between themselves in terms of quantity and serum SAA value in animals with dual infection was very close of animals with single infection. 
Hepcidin may be one of the most significant mediator of anemia of inflammation (Weinstein et al. 2002). Hepcidin is also a type II acute-phase protein that has a relation between inflammation, resulting anemia, and iron metabolism. In animal models, hepcidin levels have been shown to increase with inflammation and iron loading (Nemeth et al. 2003). Hepcidin values has not been studied in cattle diseases. In humans, hepcidin levels were evaluated in various diseases however there is no working in the field of veterinary medicine. In this study we have tried to measure the values of hepcidin in animals with single and dual infectious diseases for the first time. In the present study, serum hepcidin values were not differ between the three trial groups. But significant differences were detected compared to control group $(\mathrm{P}<0.001)$. In this study, haptoglobin analysis results were similar to the results of hepcidin analysis. According to these results, we can suggest that the hepcidin can be used as a marker for the prognosis of the diseases. Also by this study, we have tried to demonstrate the normal ranges of hepcidin in 22 clinically healthy cows $(15.93 \pm 0.84 \mathrm{ng} / \mathrm{ml})$.

\section{References}

1. Eckersall PD, Bell R. 2010. Acute phase proteins: Biomarkers of infection and inflammation in veterinary medicine. The veterinary Journal. 185(1): 23-27.

2. Eckersall PD. 2000. Recent advances and future prospects for the use of acute phase proteins as markers of disease in animals. Revue de Medicine Veterinaire.151(7): 577-584.

3. Genheim C, Hultén C, Carlsson U, et al. 2003. The acute phase response in calves experimentally infected with Bovine Viral Diarrhoea Virus and/or Mannheimia haemolytica. Journal of Veterinary Medicine, Series B. 50(4): 183-190.

4. Hamers C, Dehan P, Couvreur B, et al. 2001. Diversity among bovine pestiviruses. The Veterinary Journal. 161(2):112-122.

5. Jawor P, Stefaniak T. 2011. Acute Phase Proteins in Cattle. In: Acute Phase Proteins as Early Non-Specific Biomarkers of Human and Veterinary Diseases, Francisco Veas (Ed.), InTech, pp. 381-408.
6. Krause A, Neitz S, Magert HJ, et al. 2000. LEAP-1, a novel highly disulfide-bonded human peptide, exhibits antimicrobial activity. FEBS Lett. 480(2-3):147-150.

7. Lindberg ALE. 2003. Bovine Viral Diarrhoea Virus Infections and its Control. A review. Veterinary Quarterly. 25(1): 116.

8. Nemeth E, Valore EV, Territo $M$, et al. 2003. Hepcidin, a putative mediator of anemia of inflammation, is a type II acutephase protein. Blood. 101(7): 2461-2463.

9. Park $\mathrm{CH}$, Valore EV, Waring $\mathrm{AJ}$ et al. 2001. Hepcidin, a urinary antimicrobial peptide synthesized in the liver. The Journal of Biological Chemistry. 276 (11): 7806-7810.

10. Radostits OM, Gay CC, Hinchcliff $\mathrm{KW}$, et al. 2008. Bovine virus diarrhea, mucosal disease. Bovine pestivirus disease complex. In: Veterinary Medicine: A Textbook of Diseases of Cattle, Horses, Sheep, Pigs, and Goats, 10th edn. Saunders Elsevier, pp.1248-1277. 
11. Risalde MA, Molina V, Sanchez-Cordon PJ et al. 2011. Response of proinflammatory and anti-inflammatory cytokines in calves with subclinical bovine viral diarrhea challenged with bovine herpesvirus-1. Veterinary Immunology and Immunopathology. 144(1-2): 135-143.

12. Smith BP. 2009. Large Animal Internal Medicine. Mosby, Elsevier, St. Louis.

13. Srikumaran S, Kelling $\mathrm{C}$, Ambagala A. 2008. Immune evasion by pathogens of bovine respiratory disease complex. Anim Health Res Rev. 8 (2): 215-229.
14. Swasdipan S, McGowan M, Phillips N, et al. 2002. Pathogenesis of transplacental virus infection: pestivirus replication in the placenta and fetus following respiratory infection. Microbial Pathogenesis. 32(2):49-60.

15. Weinstein DA, Roy CN, Fleming MD, et al. 2002. Inappropriate expression of hepcidin is associated with iron refractory anemia: implications for the anemia of chronic disease. Blood. 100 (10): 37763781 . 